\title{
Effect of Plant Extracts against Bipolaris sorokiniana under in vitro and in vivo Conditions
}

\author{
Pankaj Tiwari* and Ramesh Singh \\ Department of Plant Pathology, T.D. P.G. College Jaunpur, India \\ *Corresponding author
}

\section{A B S T R A C T}

\begin{tabular}{|c|}
\hline Keywords \\
\hline $\begin{array}{l}\text { Plant extract, } \\
\text { Bipolaris } \\
\text { sorokiniana }\end{array}$ \\
\hline Article Info \\
\hline $\begin{array}{l}\text { Accepted: } \\
\text { 20 January } 2021 \\
\text { Available Online: } \\
\text { 10 February } 2021\end{array}$ \\
\hline
\end{tabular}

\section{Introduction}

Wheat (Triticum aestivum L.) belongs to family Graminae, is one of the oldest and most important cereal crops. Since antiquity, wheat was cultivated in Mohanjo-Daro and Harappa nearly 5000 years back (Pal, 1966). In India, three species of wheat are cultivated, Triticum aestivum, T.duram, and T.dicoccum (Gupta, 2004). Bread wheat accounts for approximately 95 per cent of the wheat grown, while 4 per cent is duram wheat and 1 per cent is dicoccum wheat (Gupta, 2004). Wheat is believed to have originated in South-west part of Asia. Some of the earliest remains of the crop have been found in Syria, Jordan and Turkey (Feldman, 2001). Wheat serves as a staple food for more than one billion people in the world and contributes about 20 per cent of total food calories for human being. Nearly 55 per cent of carbohydrate and 20 per cent of food calories of human diet are obtained from wheat. Wheat grain contains all essential nutrients including carbohydrate (60 to 80 per cent mainly as starch), proteins (8 to 15 per cent) containing adequate amount of all essential amino acid except lysine, tryptophan and methionine, fats (1.5 to 2 per cent), minerals (1.5 to 2 per cent), vitamins and 2.2 per cent crude fibre (Breiman and Graur, 1995).

The wheat cultivation in the warmer and humid region of North-eastern plain zone has 
extended significantly after green revolution; however, many new diseases and pest problems have been encountered by this crop that created significant yield loss. Wheat crop is affected by many fungal diseases and likely to be exposed to various types of foliar diseases other than rust, powdery mildew, Karnal bunt and loose smut. Among these spot blotch emerged as number one problem in hot and humid wheat cultivating regions (Van Ginkel and Rajaram, 1998).

Yield losses due to foliar blights are variable and in last two decades spot blotch has emerged as serious concern for wheat cultivation in the developing world. Spot blotch has been considered as a major constraint to wheat yields in South Asia due to reduction in 1000-grain weight and grain yield (Singh et al., 2007).

Annual yield loss of wheat due to this disease in South Asia is estimated to 15 to 20 per cent (Duveiller and Sharma, 2009). In India, losses due to diseases may be 10 to 50 per cent which can be devastating for farmers in the Eastern Gangetic Plains (EGPs) and depends on the level of resistance in a cultivar against leaf blight and weather conditions.

Spot blotch of wheat has emerged as serious concern for wheat cultivation in warmer and humid regions of world including South-east Asian countries such as India, Nepal and Bangladesh (Acharya et al., 2011; Chowdhary et al., 2013). Iftikhar et al., (2009) reported that Bipolaris sorokiniana caused serious foliar disease in South Asian countries. Bahadar et al., (2016) concluded that spot blotch caused by Bipolaris sorokiniana is a major disease of wheat in warm and humid regions of the world including South-east Asian countries such as India, Nepal and Bangladesh and the disease is very significant, especially in North Eastern Plains Zone (NEPZ) of India.
Akhter et al., (2006) tested inhibition of conidial germination of Bipolaris sorokiniana using eight ethanolic plant extracts, ten aqueous plant extracts in combination with cow dung and five aqueous plant extracts in combination with cow urine. Hundred percent inhibition of conidial germination was with the application of ethanolic extracts of Adhatoda vasica (leaf) and Zingiber officinale (rhizome) at 2.5 per cent concentration. After the treatment with Vinca rosea, Piper betle and Azadirachta indicaextracts in combination with cow dung suspension showed 100 per cent inhibition of conidial germination; where the lowest was noted in case of Rauwolfia serpentine (30 per cent) extract at same concentration. At 2.5 per cent concentration of Calotropis procera extracts in combination with cow urine, 91 per cent inhibition of conidial germination was observed. In most cases, Ocimum sanctum extract exhibited less inhibitory effect against B. sorokiniana.

Islam et al., (2006) applied eight plant extracts and Vitavax-200 against leaf spot (Bipolaris sorokiniana) of wheat and reported that onion, garlic, kalijira, ginger, biskatali and neem extract showed statistically similar grain yield as that of seed treatment with vitavax-200.

Malik et al., (2008) tested efficacy of foliar spray of 10 different botanicals and reported that the leaf extract of Rauwolfia serpentine at 10concentrations, significantly inhibited the spore germination up to 93.7 per cent and increased grain yield by 28.9 per cent over the check when applied as foliar sprays in the field.

Khalaf et al., (2011) found that garlic extract treatment of wheat seeds significantly reduce the incidence of seed-borne fungi, increase seed germination, number of healthy seedlings and vigour index. 
Hasan et al., (2012) evaluated the effect of five botanical extracts namely garlic, onion, ginger, neem and black cumin at different concentrations $(5,10$ and 15 per cent) on the mycelial growth of $B$. sorokiniana and showed that the highest per cent inhibition of mycelial growth was observed in the application of garlic extracts (67.50 per cent) at 15 per cent concentration.

Hasan (2013) reported that among the ten plant extracts tested, garlic bulb, margosa leaf and ginger rhizome extract significantly reduced the seed-borne fungal infections as well as the population of individual target fungi Bipolaris sorokiniana, Fusarium graminearum, Aspergillus flavus and Alternaria alternata. Perelloet al., (2013) reported that Allicin in garlic juice inhibited radial colony growth of Drechslera triticirepetis, Bipolaris sorokiniana and Septoria tritici on agar plates and spore germination.

Katooli et al., (2014) reported that eucalyptus essential oil at all concentration completely inhibited the mycelial growth of Pythium ultimum and Rhizoctonia solani only.In case of B. sorokiniana complete inhibition was only upto 5 days, after that there was mycelial growth.

Yadav et al., (2015) evaluated extracts of eucalyptus leaf, garlic clove, neem leaf and neem cake and found that two applications of aqueous Eucalyptus leaf extract at tillering and boot leaf stage resulted in the higher wheat yield as compared to other botanical extracts.

\section{Materials and Methods}

Effect of plant extract on radial growth of Bipolaris sorokiniana

Six plant extracts namely, Galic, Onion, Ginger, Eucalyptus, Neem and Black cumin were evaluated against $B$. sorokiniana in vitro by following the poison food technique. List of plant extracts used in the present study with their common name, scientific name and plant part used are given in Table 1.

Cold water extract of the leaves of eucalyptus and neem, rhizome of ginger, bulb of onion, clove of garlic and seed of black cumin were evaluated against $B$. sorokiniana in vitro to evaluate their inhibitory effect on the growth of the fungus. For preparation of cold water extracts, fresh leaves, cloves, bulbs, rhizome and seeds as the case may be were washed with tap water followed by distilled water. It was then processed with distilled water in 1:1 ratio, i.e. 100 gram tissue in $100 \mathrm{ml}$ distilled water. The plant parts were crushed in mortar and pestle and strained through double layer muslin cloth. This formed the standard extract solution $(100 \%)$.

The plant extracts were incorporated into potato dextrose agar medium at three different concentrations, i.e. 2, 5 and 10 per cent. For obtaining 2, 5 and 10 per cent concentrations of plant extracts in the medium 2, 5 and $10 \mathrm{ml}$ of plant extracts, respectively, were added in PDA to make volume $100 \mathrm{ml}$. Streptomycin $30 \mathrm{ppm}$ and Penicillium $125 \mathrm{ppm}$ were also added to the medium before pouring in the Petri-plates to prevent bacterial contamination. PDA not amended with extract served as check.

The amended PDA @ 20 ml/plate was poured into $90 \mathrm{~mm}$ sterilized Petri-plates, aseptically. Four plates were poured for each treatment. All the Petri-plates were inoculated with 5 mm mycelia disc of 7 days old culture of $B$. sorokiniana and incubated at $28 \pm 1^{\circ} \mathrm{C}$ for 7 days and observations were recorded on radial growth and sporulation. The data were converted in per cent inhibition of growth over check by using the formula as described earlier. 
Effects of spraying of plant extracts on spot blotch of wheat

Effects of spraying of six plant extracts namely, Garlic, Onion, Ginger, Eucalyptus,
Neem and Black cumin on spot blotch of wheat under field conditions were evaluated during Rabi 2018-19 and 2019-20 at University Farm. The experiment was laid out (as per details given below:

\begin{tabular}{|c|c|}
\hline Design & Randomized Block Design (RBD) \\
\hline Treatments & Plant extracts \\
\hline $\mathbf{T}_{\mathbf{1}}$ & Two sprays of Garlic clove extracts @ 5\% at 15 days intervals \\
\hline $\mathbf{T}_{\mathbf{2}}$ & Two sprays of Ginger rhizome extracts @ 5\% at 15 days intervals \\
\hline $\mathbf{T}_{\mathbf{3}}$ & Two sprays of Neem leaf extracts @ 5\% at 15 days intervals \\
\hline $\mathbf{T}^{4}$ & Two sprays of Onion bulb extracts @ 5\% at 15 days intervals \\
\hline $\mathbf{T}_{\mathbf{5}}$ & Two sprays of Eucalyptus leaf extracts @ 5\% at 15 days intervals \\
\hline $\mathbf{T}_{\mathbf{6}}$ & Two sprays of Black cumin extracts @ 5\% at 15 days intervals \\
\hline $\mathbf{T}_{\mathbf{7}}$ & Check (water Spray) \\
\hline Replications & 4 \\
\hline Variety & $\mathrm{HD}-2733$ \\
\hline Plot size & $5 \mathrm{~m} \times 2 \mathrm{~m}$ \\
\hline Seed rate & $120 \mathrm{~kg} / \mathrm{ha}$ \\
\hline Row to row distance & $20 \mathrm{~cm}$ \\
\hline Fertilizer & $120 \mathrm{~kg} \mathrm{~N}: 60 \mathrm{~kg} \mathrm{P}_{2} \mathrm{O}_{5}: 40 \mathrm{~kg} \mathrm{~K} \mathrm{~K}_{2} \mathrm{O}$ \\
\hline Date of sowing & 2018 and $25^{\text {th }}$ November 2019 \\
\hline
\end{tabular}

In neem and eucalyptus, leaves were taken whereas clove, bulb, rhizome and seed were taken in case of garlic, onion, zinger and black cumin, respectively. Standard plant extracts were prepared in cold water as per method described earlier. The extracts thus obtained were diluted to 5 per cent by water and sprayed on wheat crop. Plots sprayed with water only served as check. Two consecutive sprays at an interval of 15 days were given. Observations on disease severity were recorded at dough stage following SaariPrescot 0-9 scale as described earlier. The yield and 1000-grain weight were recorded after harvest of the crop. Data was analyzed statistically.

\section{Results and Discussion}

\section{Effect of plant extracts on radial growth of Bipolaris sorokiniana}

Six plant extracts namely garlic clove, eucalyptus leaf, neem leaf, onion bulb ginger rhizome and black cumin at 2, 5 and 10 per cent concentrations were evaluated against $B$. sorokiniana by poison food technique on potato dextrose agar medium. Data on the effect of three concentrations of six plant extracts on the radial growth of $B$. sorokiniana is presented in Table 2.

Data presented in Table 2 clearly indicates that none of the plant extracts could completely inhibit the growth of $B$. sorokiniana even at 10 per cent concentration. Eucalyptus leaf extract was highly effective in inhibiting the growth of $B$. sorokiniana as after seven days of incubation it produced 63.11, 68.24and 78.82 per cent growth inhibition of $B$. sorokiniana at 2, 5 and 10 per cent concentration, respectively. Garlic clove extract was also very promising in inhibiting the growth of $B$. sorokiniana as it produced 54.80, 65.20 and 74.62 per cent growth inhibition of B. sorokiniana at 2, 5 and 10 per cent concentration, respectively. Growth inhibition produced by eucalyptus leaf extract after seven days of incubation was significantly more than those produced by 
garlic clove extracts. Next to garlic clove extracts, neem leaf extract had also good potential in inhibiting the growth of $B$. sorokiniana as it produced 43.60, 61.57 and 73.66 per cent growth inhibition of $B$. sorokiniana at 2,5 and 10 per cent concentration, respectively. Growth inhibition produced by garlic clove extract and neem leaf extracts were statistically at par at all the three concentrations tested except two per cent concentration at which garlic clove extracts was statistically superior than neem leaf extract in inhibiting growth of $B$. sorokiniana in culture. Onion bulb and black cumin seed extracts were effective to some extent only as they produced 18.82, 35.96 and 49.11 percent and $28.74,44.40$ and 49.78 per cent growth inhibition of B. sorokiniana at 2, 5 and 10 per cent concentration, respectively. Onion bulb extract was statistically superior than black cumin seed extract at 2 and 5 per cent concentration in inhibiting the growth of fungus, however at 10 per cent concentration both were equally effective. Ginger rhizome extract was least inhibitory to $B$. sorokiniana as it produced 14.52, 30.96 and 48.29 per cent growth inhibition at 2, 5 and 10 per cent concentration, respectively. Data presented in Table 2 clearly indicates that eucalyptus leaf, garlic clove and neem leaf extract were very promising in controlling $B$. sorokiniana at all three concentrations. Onion bulb, black cumin seed and ginger rhizome extract were also effective in inhibiting $B$. sorokiniana at 5 and 10 per cent concentrations but they were either less effective or practically noneffective in inhibiting the growth of $B$. sorokiniana at two per cent concentration.

\section{Effect of foliar spraying of plant extracts} on spot blotch, yield and 1000-grain weight of wheat

The experiment was conducted in Randomized Block Design with four replications during 2018-19 and 2019-20 to find out the effect of foliar spraying of plant extracts on spot blotch, yield and 1000-grain weight of wheat. Six plant extracts namely, garlic clove, eucalyptus leaf, neem leaf, onion bulb, ginger rhizome and black cumin were tested in field condition. All six plant extracts were tested at five per cent concentration in wheat field.

\section{Effect on progress of spot blotch of wheat}

Five observations on Per cent Disease Index (PDI) and leaf blotch score (dd) were taken at fifteen and seven days intervals during Rabi 2018-19 and 2019-20, respectively. Data obtained on the effect of foliar spraying of plant extracts on disease progress of spot blotch of wheat is presented in Table 3 .

Data presented in Table 3 clearly indicates that in both the years, initially there was not much difference in PDI observed in different plant extract treatments. In Rabi 2018-19 and 2019-20, at initial stage PDI ranged from 8.72 to 12.96 and 7.21to 12.72 per cent, respectively; however, at final stage PDI ranged from 38.84 to 78.82 and 33.16to 75.74 per cent, respectively in different plant extract treatments. In both the years maximum PDI was recorded in untreated check which ranged from 11.37 to 78.82 and 11.68 to 75.74 per cent in 2018-19 and 2019-20,respectively and minimum PDI was recorded in plots given sprays of garlic clove extract and PDI ranged from 10.76 to 38.84 and 10.30 to 33.16 per cent in 2018-19 and 2019-20, respectively. In both the years, PDI was higher at final stage in all treatments including check in comparison to initial stage.

Similarly, in both the years at initial stage almost similar leaf blotch scores (dd) were observed in different treatments. In Rabi 2018-19 and 2019-20, at initial stage leaf blotch score (dd) ranged from 11 to 13 and 11 to 12 , respectively. With the advancement of 
crop season it increased and at final stage, leaf blotch score (dd) ranged from 37 to 65 and 35 to 67 in 2018-19and 2019-20, respectively. During both the years maximum leaf blotch score (dd) was recorded in untreated check which ranged from 13 to 65 and 12 to 67 in 2018-19 and 2019-20, respectively and minimum leaf blotch score (dd) was recorded in plots given sprays of garlic clove extract which ranged from 11 to 37 and 11 to 35 in 2018-19 and 2019-20, respectively. In both the year leaf blotch score $(\mathrm{dd})$ were higher at final stage in all treatments including check as compared to initial stage.

Table.1 Common name, scientific name and plant part used of the plant extracts

\begin{tabular}{|l|c|c|}
\hline Common name & Scientific name & Plant part used \\
\hline Garlic & Allium sativum & Clove \\
\hline Onion & Allium cepa & Bulb \\
\hline Ginger & Zingiberofficinale & Rhizome \\
\hline Eucalyptus & Eucalyptus globulus & Leaf \\
\hline Neem & Azadirachta indica & Leaf \\
\hline Black cumin & Nigella sativa & Seed \\
\hline
\end{tabular}

Table.2 Effect of plant extracts on radial growth of Bipolaris sorokiniana

\begin{tabular}{|l|c|c|c|c|c|}
\hline Plant extract & $\begin{array}{c}\text { Concentration } \\
(\boldsymbol{\%})\end{array}$ & \multicolumn{2}{|c|}{$\begin{array}{c}\text { Colony } \\
\text { diameter }\end{array}$} & \multicolumn{2}{c|}{$\begin{array}{c}\text { Growth inhibition over } \\
\text { check }\end{array}$} \\
\cline { 2 - 5 } & & 5 days & 7 days & 5 days & 7 days \\
\hline Garlic clove & 2 & 30.41 & 34.46 & 53.46 & 54.80 \\
\hline & 5 & 26.20 & 27.88 & 59.72 & 66.20 \\
\hline Eucalyptus leaf & 10 & 17.11 & 20.21 & 73.81 & 74.62 \\
\hline & 2 & 24.28 & 29.92 & 61.02 & 63.11 \\
\hline & 5 & 23.94 & 25.66 & 64.20 & 68.24 \\
\hline Neem leaf & 10 & 16.21 & 17.11 & 75.30 & 78.82 \\
\hline & 2 & 38.20 & 44.86 & 41.40 & 43.60 \\
\hline & 5 & 28.60 & 31.02 & 56.20 & 61.57 \\
\hline Onion bulb & 10 & 20.60 & 21.11 & 68.60 & 73.66 \\
\hline & 2 & 58.68 & 65.20 & 9.80 & 18.82 \\
\hline & 5 & 43.40 & 51.40 & 33.48 & 35.96 \\
\hline Ginger rhizome & 10 & 35.27 & 41.20 & 46.28 & 49.11 \\
\hline & 2 & 57.82 & 68.74 & 11.98 & 14.52 \\
\hline & 5 & 47.11 & 55.40 & 27.96 & 30.98 \\
\hline Black cumin & 10 & 40.20 & 41.40 & 38.31 & 48.29 \\
\hline & 2 & 47.60 & 57.20 & 26.11 & 28.74 \\
\hline & 5 & 43.72 & 44.20 & 33.22 & 44.40 \\
\hline Check & 10 & 40.11 & 40.20 & 38.80 & 49.78 \\
\hline CD 5\% & & 65.74 & 80.52 & - & - \\
\hline SE(m) & & & & 5.90 & 3.12 \\
\hline
\end{tabular}

*Average of 4 replications 
Table.3 Effect of foliar spraying of plant extracts on disease progress of spot blotch of wheat

\begin{tabular}{|l|c|c|c|c|c|c|c|c|}
\hline \multirow{2}{*}{ Plant product } & \multicolumn{4}{|c|}{$\begin{array}{c}\text { Per cent Disease Index } \\
\text { (PDI)* }\end{array}$} & \multicolumn{3}{c|}{ Leaf blotch score (0-9dd)* } \\
\cline { 2 - 9 } & $2018-19$ & 2019 & -20 & $2018-19$ & $2019-20$ \\
\cline { 2 - 9 } & Initial & Final & Initial & Final & Initial & Final & Initial & Final \\
\hline Garlic clove & 10.76 & 38.84 & 10.30 & 33.16 & 12 & 37 & 11 & 35 \\
\hline Ginger rhizome & 8.72 & 66.92 & 9.16 & 61.30 & 11 & 46 & 12 & 56 \\
\hline Neem leaf & 10.86 & 51.42 & 12.72 & 49.16 & 12 & 46 & 12 & 46 \\
\hline Onion bulb & 12.96 & 59.62 & 11.85 & 53.05 & 11 & 55 & 11 & 47 \\
\hline Eucalyptus leaf & 9.50 & 42.40 & 8.84 & 37.60 & 12 & 44 & 12 & 36 \\
\hline Black cumin & 12.71 & 73.02 & 7.21 & 67.40 & 12 & 56 & 11 & 58 \\
\hline Check & 11.37 & 78.82 & 11.68 & 75.74 & 13 & 65 & 12 & 67 \\
\hline CD 5\% & 2.43 & 2.14 & 2.12 & 1.81 & & & & \\
\hline SE(m) & 0.81 & 0.72 & 0.71 & 0.62 & & & & \\
\hline
\end{tabular}

*Average of 4 replications

Table.4 Effect of foliar spraying of plant extracts on Per cent Disease Index (PDI), yield, 1000grain weight of wheat

\begin{tabular}{|l|c|c|c|c|c|c|c|c|c|}
\hline \multirow{2}{*}{ Plant product } & \multirow{2}{*}{$\begin{array}{c}\text { Dose } \\
(\%)\end{array}$} & \multicolumn{2}{|c|}{ PDI (\%)* } & \multicolumn{2}{c|}{$\begin{array}{c}\text { Disease control over } \\
\text { check (\%)* }\end{array}$} & \multicolumn{2}{|c|}{ Yield (q/ha)* } & \multicolumn{2}{|c|}{$\begin{array}{c}\text { 1000-grain weight } \\
\text { (g)* }\end{array}$} \\
\cline { 3 - 11 } & & $2018-19$ & $2019-20$ & $2018-19$ & $2019-20$ & $2018-19$ & $2019-20$ & $2018-19$ & $2019-20$ \\
\hline Garlic clove & 5 & 38.82 & 33.16 & 50.60 & 56.15 & 41.50 & 44.74 & 42.80 & 45.62 \\
\hline Ginger rhizome & 5 & 66.92 & 61.36 & 15.01 & 18.8 & 37.76 & 39.01 & 40.22 & 41.61 \\
\hline Neem leaf & 5 & 51.42 & 49.11 & 34.60 & 35.04 & 39.40 & 41.01 & 39.50 & 43.08 \\
\hline Onion bulb & 5 & 59.70 & 53.03 & 24.22 & 29.86 & 37.78 & 39.40 & 38.60 & 39.62 \\
\hline Eucalyptus leaf & 5 & 42.40 & 37.60 & 46.11 & 50.20 & 40.11 & 43.20 & 41.60 & 43.12 \\
\hline Black cumin & 5 & 73.01 & 67.40 & 7.30 & 10.92 & 35.74 & 36.78 & 38.90 & 40.10 \\
\hline Check & & 78.85 & 75.74 & - & - & 32.40 & 33.74 & 36.07 & 37.90 \\
\hline CD 5\% & & 2.14 & 1.790 & 3.82 & 2.31 & 2.66 & 3.33 & 2.45 & 2.66 \\
\hline SE(m) & & 0.72 & 0.61 & 1.27 & 0.76 & 0.87 & 1.12 & 0.82 & 0.90 \\
\hline
\end{tabular}

*Average of 4 replications

Data presented in Table 3 clearly indicates that initially in the both years, almost similar PDI and leaf blotch score were observed in different plant extract treatments but with the advancement of season development of disease was different in different treatments and finally in both the years differences in PDI as well as leaf blotch score in different plant extract treatments were prominent or visible. 
Effect on yield and 1000-grain weight of wheat

Data on the effect of two sprays of six plant extracts namely, garlic clove, eucalyptus leaf, neem leaf, onion bulb, ginger rhizome and black cumin on yield and 1000-grain weight along with Per cent Disease Index (PDI) and per cent disease control, during Rabi 2018-19 and 2019-20is presented in Table 4.

Data presented in Table 4 reveals that all plant extracts tested significantly reduced PDI when compared with untreated check during both the years. Plant extracts gave 7.30 to 50.60 per cent disease control in the year 2018-19 and 10.92 to 56.15 per cent disease control in the year 2018-19, respectively. Garlic clove extract @ 5 per cent showed minimum PDI of 38.82 and 33.16 per cent with maximum disease control of 50.60 and 56.15 per cent over check during 2018-19 and 2019-20, respectively and was statistically superior than all other treatments except eucalyptus leaf extract which at five per cent concentration gave 46.11 and 50.20 per cent disease control over check during 2018-19 and 2019-20, respectively. Other plant extracts could produce less than 40 per cent disease control over check. Minimum disease control of 7.30and 10.92 per cent was observed during 2018-19 and 2019-20, respectively in case of black cumin, indicating that black cumin was least effective in controlling spot blotch. Yield and 1000-grain weight observed in garlic clove and eucalyptus leaf extracts (two best plant extracts) were statistically at par during both the years. Yields were 41.40 and $40.11 \mathrm{q} / \mathrm{ha}$ in case of garlic clove and eucalyptus leaf extract in 2018-19 and 44.74 and $43.20 \mathrm{q} / \mathrm{ha}$ in 2018-19, respectively. Similarly 1000-grain weights were 42.80 and $41.60 \mathrm{~g}$ in 2018-19 and 45.62 and $43.12 \mathrm{~g}$ in 2018-19.Data clearly indicates that both garlic clove and eucalyptus leaf extracts are equally effective in reducing disease to 50 per cent and increasing grain yield.

\section{In vitro screening of plant extracts against radial growth of Bipolaris sorokiniana}

Present studies clearly indicate that eucalyptus leaf, garlic clove and neem leaf extract were very promising in controlling $B$. sorokiniana at all three concentrations $(2,5$ and 10 per cent).

Onion bulb, black cumin seed and ginger rhizome extract were also effective in inhibiting $B$. sorokiniana at 5 and 10 per cent concentrations but they were either less effective or practically non-effective in inhibiting the growth of $B$. sorokiniana at two per cent concentration. Hasan et al., (2012) who evaluated the effect of five botanical extracts namely garlic, onion, ginger, neem and black cumin at different concentrations $(5,10$ and 15 per cent) on the mycelial growth of $B$. sorokiniana, showed that the highest per cent inhibition of mycelial growth was in the application of garlic extracts (67.50 per cent) at 15 per cent concentration. Perelloet al., (2013) reported that Allicin in garlic juice inhibit radial colony growth of Drechsleratritici-repetis, Bipolaris sorokiniana and Septoriatritici on agar plates and spore germination. Katooli et al., (2014) reported that eucalyptus essential oil at all concentration completely inhibited the mycelial growth of Pythiumultimum and Rhizoctonia solani only. In case of $B$. sorokiniana complete inhibition was only up to 5 days, after that there was mycelial growth. Bahadar et al., (2016) have reported that essential oil and ethanol extract of flowering buds were most effective and no inhibitory effect was noticed for the aqueous extract of leaves and bark in combating the pathogen. This is in contradiction to our present finding. 
Effect of foliar spraying of plant extracts on spot blotch, yield and 1000-grain weight of wheat

Present findings clearly indicate that all the plant extracts tested by spraying twice @ 5 per cent significantly reduced PDI when compared with untreated check during both the years. However, maximum disease control which could be achieved in either year was not more than 57 per cent and it was recorded in plots sprayed with garlic clove extract. Yield and 1000-grain weight observed in garlic clove and eucalyptus leaf extracts (two best plant extracts) were statistically at par during both the years. This clearly indicates that both garlic clove and eucalyptus leaf extracts are equally effective in reducing disease to 50 per cent and increasing grain yield.

Earlier Hassan et al., (2005) reported garlic extract completely controlled the intensity of $B$. sorokiniana and Fusarium spp. after the treatment of wheat seeds. Khalaf et al., (2011) found that garlic extract treatment of wheat seeds significantly reduce the incidence of seedborne fungi, increase seed germination, number of healthy seedlings and vigour index. Hasan (2013) reported that among the ten plant extracts tested, garlic bulb, margosa leaf and ginger rhizome extract significantly reduced the seed-borne fungal infections as well as the population of individual target fungi Bipolaris sorokiniana, Fusarium graminearum, Aspergillus flavus and Alternaria alternata. Yadav et al., (2015) evaluated extracts of eucalyptus leaf, garlic clove, neem leaf and neem cake and found that two applications of aqueous Eucalyptus leaf extract at tillering and boot leaf stage resulted in the higher wheat yield as compared to other botanical extracts. Our findings are similar to earlier findings and based on present studies it can be said that garlic clove extract and eucalyptus leaf extract can be safely used in place of fungicides for the management of spot blotch of wheat to some extent.
In conclusion among plant extracts eucalyptus leaf extract was highly effective in inhibiting the growth of $B$. sorokiniana it produced 63.11 , 68.24 and 78.82 per cent inhibition at 2, 5 and 10 per cent concentrations, respectively. Garlic clove extract was second best plant extract in inhibiting the growth of $B$. sorokiniana.

All the six plant extracts (garlic clove, eucalyptus leaf, neem leaf, onion bulb, ginger rhizome and black cumin) could significantly reduce PDI when compared with untreated check. Two sprays ofgarlic clove and eucalyptus leaf extracts@ five per cent are equally effective in reducing disease to 50 per cent and increasing grain yield.

\section{References}

Acharya, K., Dutta, A.K. and Pradhan, P. (2011). Bipolaris sorokiniana (Sacc.) Shoem.: The most destructive wheat fungal pathogen in the warmer areas. Aust. J. Crop Sci.5: 1064-1071.

Akhter, N., Begum, M.F., Alam, S. and Md. Alam, S. (2006). Inhibitory effect of different plant extracts, cow dung and cow urine on conidial germination of Bipolaris sorokiniana. J. Bio. Sci.14: 8792.

Bahadar, K., Munir, A. and Asad, S. (2016). Management of Bipolaris Sorokiniana the causal pathogen of Spot Blotch of Wheat by Eucalyptus Extracts. J. Plant. Pathol. Microbiol.7: 326.

Breiman, A. and Graur, D. (1995). Wheat Evaluation. Israel J. Pl. Sci. 43: 58-95.

Chowdhary, A.K., Singh, G., Tyagi, B.S., Ojha, A., Dhar, T. and Battacharya, M.P. (2013). Spot blotch disease of wheat-a new thrust area for sustainable productivity. J. Wheat Res. 5: 1-11.

Duveiller, E. and Sharma, R.C. (2009). Genetic improvement and crop management strategies to minimize yield losses in warm non-traditional wheat growing areas due to spot blotch pathogen Cochliobolus sativus. J. Phytopathol., 
157(9): 521-534.

Feldman, M. (2001). The origin of cultivated wheat. In:The wheat Book. A. Bonjean and W. Angus (eds.) (Paris: Lavoisier Tech. \& Doc), pp. 1-56.

Gupta, R.K. (2004). Quality of Indian wheat and infrastructure for analysis. In: Joshi, A.K., Chand, R., Arun, B., Singh, G. (eds.) A compendium of the training program (26-30 December, 2003) on wheat improvement in eastern and warmer regions of India: Conventional and non-conventional approaches. NATP project, (ICAR), BHU, Varanasi, India.

Hasan, M.M., (2013). Antifungal effect of plant extracts on seed-borne fungi of wheat. Bangladesh J. Prog. Sci.Techn.11(1): 1320.

Hasan, M.M., Ahmed, F., Islam, M.R. and Murad, K.F.I. (2012).In vitro effect of botanical extracts and fungicides against Bipolaris sorokiniana, causal agent of leaf blotch of barley. J. Agrofor. Environ.6(1): 83-87.

Hasan, M.M., Chowdhury, S.P., Shahidul, A., Hossain, B. and Alam, M.S. (2005). Antifungal effects of plant extracts on seed-borne fungi of wheat seed regarding seed germination, seedling health and vigor index. Pak. J. Biol. Sci. 8: 1284 1289.

Iftikhar, S., Shahzad, A., Munir, A. and Ahmed, I. (2009). Chracterization of Bipolaris sorokiniana isolated from different AgroEcological zones of wheat production in Pakistan. Pak. J. Bot. 41(1): 301-308

Islam, M.A., Aminuzzaman, F.M., Islam, M.R. and Zamal, M.S. (2006). Seed treatment with plant extract and Vitavax-200 in controlling leaf spot (Bipolaris sorokiniana) with increasing grain yield of wheat. Int. J. Sustain. Agril. Tech.2(8):
15-20.

Katooli, N., Maghsodlo, R. and Razavi, S.E. (2014). Evaluation of eucalyptus essential oil against some plant pathogenic fungi. Int. J. Agroforestry Silviculture. 1(2): 1617.

Khalaf, A., Emad, I.H., Khalid, M.A., Mahmoud, A., Wesam, A.K., Jacob, H.J., Mohamad, A.S., Ashraf, K. and Mohamed, I.H. (2011). Identification and controlling Pythium sp. infecting tomato seedlings cultivated in Jordan Valley using garlic extract. Asian J. Pl. Pathol. 5: 84-92.

Pal, B.P. (1966). Wheat. Indian Council of Agricultural Research, New Delhi, pp. 370.

Perello, A., Noll, U. and Slusarenko, J.A. (2013). In vitro efficacy of garlic extract to control fungal pathogens of wheat. $J$. Med. Plants Res.7(24): 1809-1817.

Singh, D.P., Chowdhury, A.K. and Kumar, P. (2007). Management of losses due to seed-borne infection of Bipolaris sorokiniana and Alternaria triticina in wheat (Triticum aestivum) using seed treatment with Vitavax 200WS. Indian J. Agric. Sci. 77: 101-103.

Van Ginkel, M. and Rajaram, S. (1998). Breeding for resistance to spot blotch in wheat: Global perspective. In: Duveiller, E., Dubin, H.J., Reeves, J. \& McNab, A. (eds). Proc. Int. Workshop on Helminthosporium Diseases of Wheat: Spot Blotch and Tan Spot, CIMMYT, El Batan, Mexico, pp. 162-169.

Yadav, B. Singh, R. and Kumar, A. (2015). Management of spot blotch of wheat using fungicides, bio-agents and botanicals. Afr. J. Agric. Res.10(25): 2494-2500.

\section{How to cite this article:}

Pankaj Tiwari and Ramesh Singh. 2021. Effect of Plant Extracts against Bipolaris sorokiniana under in vitro and in vivo Conditions. Int.J.Curr.Microbiol.App.Sci. 10(02): 2422-2431. doi: https://doi.org/10.20546/ijcmas.2021.1002.287 